\title{
Dos sonhos de Kindzu e da produção dialética de lugares e não lugares em Terra sonâmbula, de Mia Couto
}

\author{
Of Kindzu's Dreams and of Dialectical Production of Places and Non-Places \\ in Mia Couto's Sleepwalking Land
}

Jorge Alves Santana

Universidade Federal de Goiás - Goiânia - Goiás - Brasil

$\diamond$

Resumo: "Naparama? Nunca eu tinha ouvido falar em gente dessa." Com essa pergunta, o narrador Kindzu, criado pelo escritor moçambicano Mia Couto, apresenta-nos um dos eixos políticos e psicossociais do romance Terra sonâmbula (1992). Acompanharemos, nesse estudo, Kindzu, perspectivado pelos simbolismos, pela razão prática e poética dos Naparamas, dinamizando estratégias multiculturais através de suas ações e da escrita de diários, para compreender seu lugar no complexo processo pós-colonial de Moçambique. Através dos diários do filho de Taímo, em narrativa mise en abyme, o velho Tuahir e o adolescente Muindiga terão elementos tradicionais e contemporâneos para a coexistência nas espacialidades tensionadas de lugares e não lugares (AUGÉ, 2010; 2012), com o objetivo de sobreviver ao corolário da guerra civil e para compreender possíveis mecanismos de reconstrução de sua nação.

Palavras-chave: Mia Couto; Terra sonâmbula; Espacialidade; Descolonização

\begin{abstract}
Naparama? Never have I heard of such people." With this question, the narrator Kindzu, created by the Mozambican writer Mia Couto, introduces us to one of the political and psychosocial center lines of the novel Sleepwalking Land (1992). We'll follow, in this study, Kindzu, by the prospect of symbolism, practical reason and the poetic of Naparamas, giving dynamism to multicultural strategies through his actions and journal writing, to understand his place in the complex Post-Colonial process in Mozambique. Through the journals of Taímo's son, in mise en abyme narrative, the old Tuahir and the teenager Muindiga will have traditional and contemporary elements to coexist in tense spatiality of places and non-places (AUGÉ, $2010 ; 2012$ ), with the purpose of surviving the corollary of the civil war and understanding possible mechanisms of the nation's reconstruction.
\end{abstract}

Keywords: Mia Couto; Sleepwalking Land; Spaciality; Decolonisation

Meu pai sofria de sonhos, saía pela noite de olhos transabertos. Como dormia fora, nem dávamos conta. Minha mãe, manhã seguinte, é que nos convocava:

- Venham: papá teve um sonho!

(Terra sonâmbula. Mia Couto, 2007, p. 6)

- Mas na estrada não é mais perigoso, Tuahir? Não é melhor esconder no mato?

- Nada. Aqui podemos ver os passantes. Está-me a compreender?

- Você sempre sabe, Tuahir.

- Não vale a pena queixar. Culpa é sua: não é você que quer procurar seus pais?

(Terra sonâmbula. Mia Couto, 2007, p. 2)

Pensar a mobilidade é pensá-la em diversas escalas para tentar compreender as contradições que minam nossa história.

(Por uma antropologia da mobilidade. Marc Augé, 2010, p. 99) 


\section{Introdução}

O escritor moçambicano Mia Couto publica seu romance Terra sonâmbula no ano de 1992. Época singular que coincide com o relativo término de uma das mais sangrentas guerras civis contemporâneas do Continente Africano. ${ }^{1}$ Tensionada entre o projeto político afro-marxista e o neoliberal de Moçambique pós-independência de Portugal, sendo que o primeiro assume o governo ao final da independência oficial, a engenharia de tal romance é montada pelos destroços do imperialismo luso-tropical. Fato que aponta para necessidades e possiblidades da reconstrução nacional, tendo em vista a desejada democracia multipartidária.

Neste contexto de múltiplos projetos políticos, sociais e culturais, acompanharemos essa narrativa literária no que ela nos sugere e fornece elementos para compreendermos, mesmo que de modo relativo, os dispositivos de produção de identidades psicossociais. Tais dispositivos estão ontologicamente dispostos em uma espacialidade complexa, e parecem estar em transe diante das novas responsabilidades de se pensar e ativar, na coexistência necessária, estratégias de reconstrução e imaginação da nação. Observamos, pois, produções individuais e, sobretudo, coletivas múltiplas e heterogêneas da sociedade moçambicana, particularmente em suas disposições de lugares e não lugares, no período pós-colonial.

Terra sonâmbula traz-nos dois grupos de moçambicanos neste contexto de guerra civil: um dos grupos é constituído por um velho, Tuahir, e por um garoto, Muidinga; o outro, por Kindzu e sua família, bem como por amigos de sua aldeia e companheiros de vários lugares pelos quais passa em sua procura pelos lendários guerreiros Naparamas. Essa narrativa romanesca é montada por suas linhas de ação dramática, dispostas em doze capítulos, sendo que há uma divisão simétrica para as duas narrativas encaixadas. $\mathrm{Na}$ primeira, acompanhamos Tuahir e Muidinga, que vagam por uma estrada afundada nos destroços da guerra e encontram diários de um moçambicano morto. Na segunda, Kindzu, o moçambicano que escreve os diários, narrando sua vida envolta em variadas aventuras em torno de sua vida familiar e de certa coletividade da vida moçambicana em guerra civil. Os primeiros lerão os diários do segundo,

\footnotetext{
1 Do ponto de vista estatístico e também qualitativo sobre a independência e a guerra civil de Moçambique, fomos influenciados pelos estudos de João Paulo Borges Coelho (jun. 2016), da Universidade Eduardo Mondlane, das mais reconhecidas do país. Para perspectivamos as questões através de estudos de africanistas, acompanhamos, mesmo que de modo indireto, Alice Dinerman (2006). Seguimos também a homepage oficial do governo moçambicano (jun. 2016), com a finalidade de compreendermos como algumas questões aqui abordadas se encontram atualmente.

2 As relações multiculturais e intergeracionais são uma constante na literatura de Mia Couto. Exemplo disso é o conto Nas águas do Tempo,
}

em dinâmica de mise em abyme, que unirá universos diversos na necessária situação de se compreender e de se construir as espacialidades e identidades dos lugares, dos não lugares e dos tempos pós-coloniais. Vejamos o início do romance:

\begin{abstract}
Naquele lugar, a guerra tinha morto a estrada. Pelos caminhos só as hienas se arrastavam, focinhando entre cinzas e poeiras. A paisagem se mestiçara de tristezas nunca vistas, em cores que se pegavam à boca. Eram cores sujas, tão sujas que tinham perdido toda a leveza, esquecidas da ousadia de levantar asas pelo azul. Aqui, o céu se tornara impossível. E os viventes se acostumaram ao chão, em resignada aprendizagem da morte. (COUTO, 2007, p. 2).
\end{abstract}

Uma estrada moçambicana é elevada à categoria de personagem de base para os núcleos acionais desse universo diegético. Transformando-se, pois, em espaço no qual os viventes predominantemente seriam ensinados a se resignarem à aprendizagem da morte. Trata-se, então, uma espacialidade em guerra civil que desconheceria os seus próprios filhos, negandolhes possibilidades de reconstrução e de reinvenção da nação, após a independência ocorrida em 25 de junho de 1975. No entanto, mais que um não lugar impeditivo da rememoração de memórias coletivas e planos para o futuro, tal estrada, e outros lugares correlatos, também possibilitarão encontros das tradições moçambicanas com crenças e valores contemporâneos.

Estes encontros entre os diversos segmentos da coletividade nacional, principalmente aqueles em crônica vulnerabilidade de direitos humanos, serão também responsáveis pela necessidade de se construir novos lugares antropológicos, nos quais os agentes sociais são chamados a se posicionarem de modo ativo e crítico em relação a si próprios, as suas relações sociopolíticas e à imaginação e às razões práticas para a reconstrução do país.

\section{Intergeracionalidade e reconstrução/ reinvenção da nação}

Os conflitos civis vivenciados por Moçambique, principalmente no período pós-colonial, concorrem para o desmonte pragmático dos laços intergeracionais ${ }^{2}$ que mantêm variadas heranças institucionais mantenedoras

\footnotetext{
do livro Terra Abensonhada (2009), no qual seguimos um avô educando seu neto sobre uma figura lendária da tradição do lugar, que é o Namwetxo Moha: um ente que surgia à noite, feito só de metades: um olho, uma perna, um braço. Essa alegoria particular do Namwetxo apontaria para a necessária dinâmica de inclusão, mesmo que de elementos diferentes e contraditórios, que produz seres e fenômenos. Para acompanhar outros tantos levantamentos culturais feitos por Mia Couto, queira ver a home-page oficial do autor (07 jun. 2016), que é prolífica e militante no propósito de divulgar tais materiais moçambicanos e dos demais países africanos para a aldeia global.
} 
da estratificada cultura nacional. Dessa forma, a diáspora populacional para fora do país e também para dentro dele mesmo, ocasiona principalmente a desestruturação dos núcleos familiares. Nesse quadro acompanhamos, em Terra sonâmbula, a derrocada da família de nosso narrador homodiegético, que é o jovem Kindzu.

Quando dos ataques cruzados entre as duas bélicas forças políticas que exigem o domínio do governo nacional, essa família fomenta a estratégia de se tornar invisível, para preservar sua ordem social e suas próprias vidas. No entanto, tal postura estratégica não os impedirá de sofrer as consequências da fragmentação sociocultural na qual o país está imerso. Kindzu, uma espécie de indivíduo que funciona como arrimo para o núcleo parental, estará impedido de localizar-se na rede intergeracional ${ }^{3}$ capaz de preservar e disseminar os elementos da cultural regional para planos mais macroculturais. Através de seus diários, vemos que o rapaz, em consequência do ambiente de guerra no qual está inserto/incerto, já não confia tanto nos valores e nas crenças ensinados pelas pessoas idosas de sua coexistência. Também já não acredita tanto na educação recebida pela instituição cristã, através das relações mantidas com o pastor Afonso. Tanto os velhos feiticeiros de sua etnia, quanto a religiosidade lusitana são colocados na berlinda, quando a terra é envolvida pelos rigores da guerra civil por tantos anos.

O núcleo acional de Tuahir e de Muindiga, no entanto, encaminha-se para o resgate dialético dessa dinâmica intergeracional. $\mathrm{O}$ velho havia resgatado o garoto quase morto de um campo de refugiados. Cura-o e o insere novamente no fluxo das vidas possíveis. Constrói, então, como que uma nova parentalidade que, mesmo entre dois indivíduos desconhecidos, terá a potencialidade de resgatar as estórias sociais e culturais tanto da tradição, quanto aquelas de sua contemporaneidade nebulosa. Vejamos como esse quadro se instaura:

Quem o recolhera fora o velho Tuahir, quando todos outros o haviam abandonado. O menino estava já sem estado, os ranhos lhe saíam não do nariz mas de toda a cabeça. O velho teve que the ensinar todos os inícios:

\footnotetext{
3 Por geração, seguimos os estudos do sociólogo húngaro Karl Mannheim (1982), que compreende essa realidade tal qual um fundante dispositivo de formação social, disposto no tempo e no espaço, envolvendo indivíduos de faixa etária diferenciada. Tal dispositivo pode ser medido por aspectos de temporalidade quantitativa; ou seja, pelo conjunto de pessoas que vive em certa medida temporal e que possuem ainda a semelhança de compartilharem de situações socioculturais semelhantes. Disso, surge uma espécie de enteléquia, o que seria o espírito da época, que homogeneizaria o leque de ações e compreensão de ações que se pode ter em comum. Os estudos de Karl Mannheim também recolocam o conceito de geração nos moldes de um fato social inserido nas variáveis temporais, sociais, psicológicas, culturais e outras. Dessa forma, o que seria a clássica unidade geracional é vista sob variáveis formações discursivas que constrói um fenômeno ontologicamente heterogêneo. Baseados nesses estudos é que discutimos aqui o dispositivo social da geração e das relações intergeracionais.
}

andar, falar, pensar. Muidinga se meninou outra vez. Esta segunda infância, porém, fora apressada pelos ditados da sobrevivência. (COUTO, 2007, p. 2).

Dois desconhecidos, premidos pelo imperativo da sobrevivência pessoal, que notadamente também dependem do conhecido das situações que ocorrem em suas proximidades pessoais e por todo o país. Estórias pessoais implicam, pois, o conhecimento das estórias familiares e, de modo mais estrutural e funcional, da coletividade heterogênea e ampliada. O velho Tuahir será capaz de criar certo contexto intergeracional, necessário aos encontros entre cronotopias passadas, cronotopias do presente e, sobretudo, as do futuro. A espacialidade de tal encontro, entre o velho e o garoto, é aquela da provisoriedade que a época possibilita: a estrada dos movimento diaspóricos do país:
- Estou-lhe a dizer, miúdo. Vamos instalar casa aqui mesmo.
- Mas aqui? Num machimbombo (autocarro) todo incendiado?
- Você não sabe nada, miúdo. O que já está queimado não volta a arder. Muidinga não ganha convencimento. Olha a planície, tudo parece desmaiado. Naquele território, tão despido de brilho, ter razão é algo que já não dá vontade. Por isso ele não insiste. Roda à volta do machimbombo. O veículo se despistara, ficara meio atravessado na rodovia. A dianteira estava amassada de encontro a um imenso embondeiro. Muidinga se encosta ao tronco da árvore e pergunta:
- Mas na estrada não é mais perigoso, Tuahir? Não é melhor esconder no mato? - Nada. Aqui podemos ver os passantes. Está-me compreender?
- Você sempre sabe, Tuahir.
- Não vale a pena queixar. Culpa é sua. Não é você que quer procurar seus pais? (COUTO, 2007, p. 2).

Percebemos como o desejo de segurança física se alia ao registro aventureiro que a necessidade de compreensão das bases identitárias ocasiona. Os dois personagens andarão por uma estrada, referencial temporário da opressão e da morte provável, e usarão um ônibus, que fora atacado e estava cheio de corpos carbonizados, como tentativa de resgate e de sobrevivência para si mesmos. Muindiga deseja conhecer sua origem e isso ocorrerá através do encontro com os diários de Kindzu, ${ }^{4}$ um dos anônimos mortos em volta do ônibus destruído.

\footnotetext{
4 O diários de Kindzu, escritos através da focalização homodiegética autotélica, dão o tom da voz relativamente própria deste protagonista. Ou seja, um jovem negro moçambicano dominando a escrita oficial e representando o mundo no qual se insere, de acordo com sua formação psicossocial. Sobre tal estratégia composicional, a de dar voz a uma personagem marginalizada, efetivada por Mia Couto, lembramo-nos de Gayatri C. Spivak $(2008 ; 2010)$ que nos alerta para a necessidade de o intelectual/artista esforçar-se por permitir que o subalterno fale por conta
} 
A narrativa literária instala-se, pois, em um lugar de densa provisoriedade: uma estrada que parece não se cruzar com qualquer outra e um ônibus incendiado que ainda apresentava, e simbolizava, os frescos sinais da morte de tantos moçambicanos deslocados de suas casas, de suas famílias, de suas culturas. Que vontade seria capaz de manter tais vidas em curso? Os diários encontrados sugerem e apontam novos caminhos, como observamos:

O miúdo se levanta e escolhe entre os papéis, receando rasgar uma folha escrita. Acaba por arrancar a capa de um dos cadernos. Para fazer fogo usa esse papel. Depois se senta ao lado da fogueira, ajeita os cadernos e começa a ler. Balbucia letra a letra, percorrendo o lento desenho de cada uma. Sorri com a satisfação de uma conquista. Vai-se habituando, ganhando despacho.

- Que estás a jazer, rapaz?

- Estou a ler.

- É verdade, já esquecia. Você era capaz ler. Então leia em voz alta que é para me dormecer.

O miúdo lê em voz alta. Seus olhos se abrem mais que a voz que, lenta e cuidadosa, vai decifrando as letras. Ler era coisa que ele apenas agora se recordava saber. O velho Tuhair, ignorante das letras, não lhe despertara a faculdade da leitura. A lua parece ter sido chamada pela voz de Muidinga. A noite toda se vai enluarando. Pratinhada, a estrada escuta a estória que desponta dos cadernos. Quero pôr os tempos... (COUTO, 2007, p.4-5).

Muidinga, apesar de seu passado desconhecido e de sua presente recuperação psicofísica, vai descobrindo-se ser leitor de textos escritos. É capaz de acompanhar, pois, a escrita deixada pelo morto Kindzu. Tuahir sabe-se analfabeto e se entrega a ouvir o exercício informativo e libertário de leitura que o garoto lhe oferece. Conhecerão juntos as estórias vivenciadas e registradas de modo meticuloso pelo autor de tais diários. Os tempos passados e presentes estão guardados e, de certa forma, exigem ser colocados em interação com os vários presentes experimentados por aqueles que ainda estão vivos. Desses passados, destaca-se a necessidade de reflexão sobre si mesmo e sobre os meios vivenciais nos quais Kindzu vê-se inserido.

A ação de colocar os tempos, como observamos no final da citação acima, em realidades concretas, une de modo dialógico e dialético as duas narrativas encaixadas. Os dois núcleos de personagens e ações se encontram,

\footnotetext{
de seu próprio estrato sociocultural. Para ela, é comum defendermos uma causa política de um povo vulnerabilizado, considerando-o como coletividade homogênea. Que devemos nos preocupar, Spivak ainda insiste, em deixar o povo subjugado ter condições de construir e consolidar sua própria capacidade de fala. Assim, a codificação de identidades heterogêneas, mesmo que através de estratégias do uso de certos essencialismos, seria uma necessidade para se tensionar os vários interesses presentes em contextos pós-coloniais, no que diz respeito à autonomia e independência dos agentes sociais envolvidos no processo.
}

mesmo que de modo não intencional, em contexto colaborativo para a compreensão e a reengenharia de seu socius. Kindzu procura por outridades que lhe expliquem o contexto bélico que o atinge, bem como a sua família e a sua coletividade moçambicana. Porém, parece não encontrar referenciais seguros no meio dos escombros da guerra. No entanto, coloca a si próprio como uma dessas fontes necessárias para se conhecer e dar certa ordem aos tempos e aos lugares, como acompanhamos:

\begin{abstract}
Quero pôr os tempos, em sua mansa ordem, conforme esperas e sofrências. Mas as lembranças desobedecem, entre a vontade de serem nada e o gosto de me roubarem do presente. Acendo a estória, me apago a $\mathrm{mim}$. No fim destes escritos, serei de novo uma sombra sem voz. Sou chamado de Kindzu. É o nome que se dá às palmeiritas mindinhas, essas que se curvam junto às praias. Quem não lhes conhece, arrependidas de terem crescido, saudosas do rente chão? Meu pai me escolheu para esse nome, homenagem à sua única preferência: beber sura (Sura: aguardente feita dos rebentos de palmeira), o vinho das palmeiras (COUTO, 2007, p. 6).
\end{abstract}

Uma espécie de psicogênese é colocada em curso nos diários de Kindzu. Há como que um resgate de crenças e valores, como por exemplo, da cultura animista que vincula os seres humanos à natureza. $\mathrm{O}$ seu próprio nome está vinculado a um dos elementos fundadores de sua cultura, que é uma palmeira. Este narrador remonta a origem de seu pai, Taímo, que outrora era produtor de uma bebida derivada do coco de uma palmeira regional, encontrava-se inativo devido à repressão que a polícia nacional fazia ao seu trabalho artesanal. É um homem, pois, que não pode mais viver de seu trabalho ancestral. Diante disso, recolhe-se a uma condição de quase inação, na qual praticamente se restringe a deambulações em seu quintal e aos variados e instigantes sonhos que tem e que insiste em comunicar, mesmo que de modo enviesado, a sua família.

Dos vários ecos culturais que Kindzu ainda consegue perceber de sua cultura, um dos que moverá sua diáspora psicossocial será o das estórias dos lendários guerreiros Naparamas. Tais guerreiros, um tanto lendários e também de referencialidade pragmática, seria capazes de trazer a paz a certos segmentos moçambicanos, vítimas dos conflitos colonialistas e pós-colonialistas. Quem eram tais guerreiros, o jovem perguntava a um de seus poucos amigos, o comerciante indiano Surendra Valá:

- Esse quem era?

- Esse é um Naparama.

Naparama? Nunca eu tinha ouvido falar em gente dessa. Surendra me explicou vagamente. Eram guerreiros tradicionais, abençoados pelos feiticeiros, que lutavam contra os fazedores da guerra. Nas terras 
do Norte eles tinham trazido a paz. Combatiam com lanças, zagaias, arcos. Nenhum tiro lhes incomodava, eles estavam blindados, protegidos contra balas.

- E esse o que veio aqui fazer?

- Veio pedir panos. Precisam deles para iniciar outros que se oferecem para ser Naparamas (COUTO, 2007, p. 13).

Os guerreiros Naparamas representarão, na economia dessa narrativa, uma possibilidade real de se conhecer, reconhecer, resgatar e difundir valores culturais que o projeto político de uma África lusitana e suas consequências pós-coloniais desconstruíram, de modo sistemático, através de séculos. Kindzu, mesmo com o não consentimento de sua família, sairá à procura de tais guerreiros, tanto para lutar ao lado deles, quanto para tentar criar o equilíbrio entre as tradições fragmentadas e os novos valores dos complexos tempos presentes que exigem a reinvenção da nação. ${ }^{5}$ Para tanto, há de se trilhar uma espacialidade cuja existência encontra-se em transe. Quais lugares e não lugares estariam dispostos nessa espacialidade sonâmbula?

\section{Latências na tensão entre lugares e não lugares}

A procura que Kindzu faz dos guerreiros Naparamas, supõe uma intricada cartografias de lugares e de não lugares. A espacialidade de tais lugares é expressa pela estrada que só aparentemente não levaria as pessoas a destino algum. De início teríamos que:

A estrada que agora se abre a nossos olhos não se entrecruza com outra nenhuma. Está mais deitada que os séculos, suportando sozinha toda a distância. Pelas bermas apodrecem carros incendiados, restos de pilhagens. Na savana em volta, apenas os embondeiros contemplam o mundo a desflorir. Um velho e um miúdo vão seguindo pela estrada. Andam bambolentos como se caminhar fosse seu único serviço desde que nasceram. Vão para lá de nenhuma parte, dando o vindo por não ido, à espera do adiante. Fogem da guerra, dessa guerra que contaminara toda a sua terra. Vão na ilusão de, mais além, haver um refúgio tranquilo (COUTO, 2007, p. 2).

\footnotetext{
5 No que diz respeito à invenção/reinvenção e imaginação da nação/ nacionalidade, embasamo-nos em Benedict Anderson (1989; 2008). Este pensador desnaturaliza o que de fato é a construção diacrônica do fenômeno nação/nacionalidade, em sua moldura sociopolítica. Anderson nos ensina que: "Afirmei, fundamentalmente, que a possibilidade mesma de se imaginar a nação só surgiu historicamente quando, e onde, três conceitos culturais básicos, todos extremamente antigos, deixaram de ter domínio axiomático sobre o pensamento dos homens. O primeiro deles era a ideia de que uma determinada língua escrita oferecia acesso privilegiado à verdade ontológica, precisamente por ser parcela inseparável daquela verdade. [...] O segundo era a crença de que a sociedade era organizada de maneira natural em torno de e sob centros elevados - monarcas que eram pessoas distintas dos outros seres humanos e que governavam por alguma forma de disposição cosmológica (divina). [...] Em terceiro lugar, a concepção de temporalidade, em que a cosmologia e a história não se distinguiam, sendo essencialmente idênticas as origens do mundo e dos homens." (ANDERSON, 2008, p. 45).
}

Para fugir da guerra que contamina a terra e a todos que dela são feitos e nela estão imersos, há de se reconstituir as espacialidades da tradição. Nesse ponto, lembramo-nos do velho Taímo, que aconselha ao filho que ele não deixe a casa de sua família. Mas que lugar familiar é esse? Na casa de Kindzu, as possibilidades de vivenciar os espaços dados estão em crise. O pai já não dorme mais dentro de casa, por exemplo. Dorme do lado de fora da casa, pois não se sente confortável no simulacro de um lar que reflete intimamente as consequências do estado de guerra civil. Em certa altura dos acontecimentos, o irmão Junhito (nome dado ao menino em homenagem à data da Independência de Moçambique: 25 de junho de 1975), que em uma estratégia alegórica dessa narrativa, é disfarçado de galo e colocado no galinheiro da casa, para safar-se de uma possível morte ocasionada pelas forças nacionais de repressão policial. Sendo que tal morte fora sonhada pelo seu pai. Soma-se a isso, o espaço inessencial representado pela canoa mortuária em que o velho pai é depositado, ao fim da desestruturação intensa na qual o espaço familiar é lançado.

Esse lugar familiar, transformado em não lugar pela guerra, é disposto em uma estrutura maior que a viagem de formação de Kindzu proporciona. Acompanhamos o rapaz chegar à comunidade de Matimati, na qual interagirá com variados segmentos humanos que representam a heterogeneidade social de Moçambique. Aí, também o vemos relacionar-se com a personagem Farida, outra singular subjetividade diaspórica do romance, envolvida com a ambiência marítima em sua relação com uma ilha e um farol, e na constante busca de seu filho desaparecido. Sendo que esse último elemento dará certa tônica de suspense ao enredo, no sentido de que a personagem Farida também estará diretamente envolvida na narrativa de Tuahir e Muidinga.

Temos, ainda nessa cartografia múltipla, mesmo que em movimentos narrativos analépticos, a casa do casal de portugueses, os campos de refugiados e a constante estrada, na qual se queimam ônibus e pessoas em procura de refúgios; sem no entanto, se queimar diários que funcionam como elos cronotópicos entre as duas realidades. A realidade de tal estrada, porém, é redimensionada de não lugar, espacialidade na qual seria relativamente difíceis os enraizamentos antropológicos, ${ }^{6}$

\footnotetext{
6 Estes enraizamentos antropológicos dizem respeito ao conceito de lugar antropológico, refletido por Marc Augé, quando o autor nos ensina que: "Reservamos o termo 'lugar antropológico' àquela construção concreta e simbólica do espaço que não poderia dar conta, somente por ela, das vicissitudes e contradições da vida social, mas à qual se referem todos aqueles a quem ela designa um lugar, por mais humilde e modesto que seja. [...] Esses lugares têm pelo menos três características comuns. Eles se pretendem (pretendem-nos) identitários, relacionais e históricos. O projeto da casa, as regras de residência, os guardiões da aldeia, os altares, as praças públicas, o recorte das terras correspondem para cada um a um conjunto de possibilidades, prescrições e proibições cujo conteúdo é, ao mesmo tempo, espacial e social. Nascer é nascer num lugar, ser designado à residência.” (AUGÉ, 2012, p. 51-52).
} 
a lugares, nos quais as estórias pessoais e coletivas tomam corpo, mesmo que provisoriamente, para que as resistências sejam produzidas e sejam criadas novas condições de coexistência pacífica. Quase ao final da narrativa, em um dos capítulos pertinentes aos diários de Kindzu, acompanhamos o que se pensa sobre essa estrada transformada em lugar de convivência e, paradoxalmente, de resistência:

- Por isso eu digo: não é o destino que conta mas o caminho. Que ele falava de uma viagem cujo único destino era o desejo de partir novamente. Essa viagem, porém, teria que seguir o respeito de seu conselho: eu deveria ir pelo mar, caminhar no último lábio da terra, onde a água faz sede e a areia não guarda nenhuma pegada. Eu que levasse o amuleto dos viajeiros e o guardasse em velha casca do fruto ncuácu. E procurasse os confins onde os homens não amealham nenhuma lembrança. Para me livrar de ser seguido por meu pai eu não podia deixar sinais do meu percurso. Minha passagem se faria igual aos pássaros atravessando os poentes (COUTO, 2007, p. 162).

O protagonista lembra-se de um ensinamento recorrente feito por sua mãe: o de que há de ser invisível nos lugares tomados pela violência da guerra. No entanto, mesmo quando se tem a estrada como marcações de ações supostamente não comprometidas com os lugares antropológicos e históricos, tal protagonista o registra de modo a reterritorializar as tradições culturais dos povos e espaços com os quais cruza em sua procura. A busca do espaço no qual os homens se silenciariam sobre seus tempos presentes também é, pois, contaminada pelos lugares que exigem que os homens se mostrem posicionados de modo firme diante desses mesmos lugares e tempos.

A narrativa, assim, tensiona o diálogo entre as temporalidades capazes de se dirigir não para o silêncio, mas para os chamados de uma terra desejosa de reconstrução, mesmo com sua aparente inoperância quanto a esses projetos libertários. Apesar da condição de sonâmbula desta terra, os variados e heterogêneos registros pessoais e coletivos insertos nos diários, bem como a realização pragmática e dialógica de sua leitura, exigem e proporcionam novos horizontes, como observamos:

À volta do machimbombo Muidinga quase já não reconhece nada. A paisagem prossegue suas infatigáveis mudanças. Será que a terra, ela sozinha, deambula em errâncias? De uma coisa Muidinga está certo: não é o arruinado autocarro que se desloca. Outra certeza ele tem: nem sempre a estrada se movimenta. Apenas de cada vez que ele lê os cadernos. (COUTO, 2007, p. 58).
Tal enfrentamento, sistemático ou assistemático, às condições adversas vivenciadas pelos personagens desse romance, não lhes tiram, no entanto, as vontades de evasão para espacialidades utópicas. Nas duas narrativas, observamos esse movimento de tentativa de afastamento da terra. Deseja-se ir, por exemplo, para o elemento aquático que envolve grande parte da fronteira oceânica de Moçambique. Tal elemento, além do seu caráter simbólico de imersão no além-África, talvez até procure compactuar-se com a proposta político-cultural de certo pan-africanismo. Ou, então, representa/ expressa a concretização daquele silêncio cautelar e protetivo frente mecanismos autoritários de forças bélicas em plena operação de destruição. Tanto na narrativa de Tuahir, quando esse velho formador e cuidador morre, quanto na narrativa de Kindzu, temos tal movimentação aparentemente de evasão. Na primeira:

As ondas vão subindo a duna e rodeiam a canoa. A voz do miúdo quase não se escuta, abafada pelo requebrar das vagas. Tuahir está deitado, olhando a água a chegar. Agora, já o barquinho balouça. Aos poucos se vai tornando leve como mulher ao sabor de carícia e se solta do colo da terra, já livre, navegável. Começa então a viagem de Tuahir para um mar cheio de infinitas fantasias. Nas ondas estão escritas mil estórias, dessas de embalar as crianças do inteiro mundo. (COUTO, 2007, p. 115).

Na segunda:

O que queria mesmo era ir mar adentro, como Assma, empurrado num barquinho sem destino. Ou fazer como minha mãe me ensinou: ser a mais delicada sombra. É isso que desejo: me apagar, perder voz, desexistir. Ainda bem que escrevi, passo por passo, esta minha viagem. Assim escritas estas lembranças ficam presas no papel, bem longe de mim. Este é o último caderno. Depois, arrumo tudo na mala que me deu Surendra. No final, Surendra é o único de quem eu aceito companhia. $\mathrm{O}$ indiano mais sua nação sonhada: o oceano sem nenhum fim. (COUTO, 2007, p. 117).

Mesmo com as latências dos simbólicos lugares aquáticos, presentes nas últimas esperanças dos personagens, eles só são assumidos quando a finitude física de fato ocorre. Os corpos mortos são neles lançados, talvez confirmando crenças místicas de que suas almas andarão a procura de metafísicos portos seguros. No entanto, essa metafísica da consolação não é a tônica do romance. Nele, os lugares e não lugares ${ }^{7}$ formam os

\footnotetext{
Por serem importantes para o desenvolvimento de nosso estudo, convém explicitarmos que os conceitos de lugar e de não lugar são desenvolvidos por Marc Augé, como começamos a desenvolver anteriormente. $\mathrm{O}$ autor reflete sobre os dois conceitos vinculados à ideia da sobremodernidade
} 
palcos reais, nos quais tais personagens são instigadas a assumir seus papéis de agentes sociais, montando seus enredos com certo conhecimento, mesmo que ainda de modo irregular e provisório, de seus contextos vivenciais.

Se o lugar real dos guerreiros Naparamas, aqueles que derrotariam os senhores da guerra, não é encontrado de modo referencial, nossos protagonistas se encontrarão na necessidade da construção premente de tal lugar desejado. A escrita e as tradições orais das culturas moçambicanas, mesmo que fortemente silenciadas, formarão os dispositivos para a construção/invenção de tais lugares, evitando assim a tensão solitária comumente produzida pelos não lugares.

\section{O último sonho de Kindzu}

O pensador e ativista Frantz Fanon, em elucidativo e ainda pertinente estudo sobre os processos de colonização e de pós-colonização, reflete, entre tantas outras temáticas de cunho político-cultural, sobre as características que envolvem o belicismo da vida dos sujeitos em processo de libertação nacional. Particularmente sobre as ambiências e possibilidades do processo de descolonização, temos que:

A descolonização, que se propõe mudar a ordem do mundo, é, está visto, um programa de desordem absoluta. Mas não pode ser o resultado de uma operação mágica, de um abalo natural ou de um acordo amigável. A descolonização, sabemo-lo, é um processo histórico, isto é, não pode ser compreendida, não encontra a sua inteligibilidade, não se torna transparente para si mesma senão na exata medida em que se faz discernível o movimento historicizante que lhe dá forma e conteúdo. A descolonização é o encontro

(surmodernité); ou seja, o que é nossa época contemporânea, composta por excessos temporais, espaciais e identitários. Assim, as espacialidades estariam dispostas em lugares e não lugares, sendo que o espaços possíveis são produzidos pelas relações sociais históricas. Para o autor, não lugar diz respeito a "um espaço empiricamente identificável (um aeroporto, um hipermercado ou um monitor de televisão), mas como o espaço criado pelo olhar que o toma como objeto, podemos admitir que o não lugar de uns (por exemplo, os passageiros em trânsito num aeroporto) seja o lugar de outros (por exemplo, os que trabalham nesse aeroporto)." (AUGE, 2012, p. 116). Enquanto que para um lugar, teríamos que: "Se um lugar pode se definir como identitário, relacional e histórico, um espaço que não pode se definir nem como identitário, nem como relacional, nem como histórico definirá um não-lugar. A hipótese aqui defendida é a de que a sobremodernidade é produtora de não-lugares, isto é, de espaços que não são em si lugares antropológicos e que, contrariamente à modernidade baudelairiana, não integram os lugares antigos: estes, repertoriados, classificados e promovidos a 'lugares de memória', ocupam aí um lugar circunscrito e específico. (AUGÉ, 2012, p. 73). Os dois tipos de espaços podem ser intercambiáveis ou hibridizados, o que não lhes confere, pois, essencialidade ontológica excludente. Aqui, enfatizamos o que seriam os não lugares cotidianos, a estrada e os campos de refugiados, bem como as consequências que esses dois lugares produzem nas trajetórias dos personagens, em condição diaspórica em seu próprio país. Tais não lugares são evidenciados como lugares antropológicos temporários, nos quais se produzem/imaginam narrativas pessoais e coletivas, alicerces para a nova nação, com seus lugares construídos de modo coletivo. de duas forças congenitamente antagônicas que extraem sua originalidade precisamente dessa espécie de substantificação que segrega e alimenta a situação colonial. Sua primeira confrontação se desenrolou sob o signo da violência, e sua coabitação - ou melhor, a exploração do colonizado pelo colono - foi levada a cabo com grande reforço de baionetas e canhões. O colono e o colonizado são velhos conhecidos. E, de fato, o colono tem razão quando diz que 'os' conhecelo. O colono que fez e continua a fazer o colonizado. O colono tira a sua verdade, isto é, os seus bens, do sistema colonial.

A descolonização jamais passa despercebida porque atinge o ser, modifica fundamentalmente o ser, transforma espectadores sobrecarregados de inessencialidade em atores privilegiados, colhidos de modo quase grandioso pela roda viva da história. Introduz no ser um ritmo próprio, transmitido por homens novos, uma nova linguagem, uma nova humanidade. A descolonização é, em verdade, criação de homens novos. (FANON, 1979, p. 26).

A citação de Fanon nos é útil para destacamos o contexto no qual, ele nos aponta que "A descolonização, sabemo-lo, é um processo histórico complexo e de longa duração, isto é, não pode ser compreendida, não encontra a sua inteligibilidade". O processo político e cultural não é tão perceptível em si mesmo. A transparência do processo de descolonização exige, pois, maior atenção e perspectivações múltiplas e heterogêneas dos colonizados. Tais sujeitos são colocados na posição de agentes sociais que resgatam, desconstroem e reconstroem as estruturas e funcionalidades de seu socius em sistemática. E nessa ação necessária "espectadores sobrecarregados de inessencialidade devem ser transformados atores privilegiados, colhidos de modo quase grandioso pela roda viva da história".

Vimos acima como nossos protagonistas são chamados constantemente pelo elemento aquático, que perfaz a geopolítica da costa oceânica de Moçambique. Essa realidade mítica, mística e social talvez lhes possibilitem certo lenitivo quanto aos horrores da guerra e as condições de refugiados internos. Tais horrores foram e ainda são bem concretos no país, tais como: destruição de plantações nas zonas rurais, de estradas e de vários outros lugares repletos de minas com alto poder destrutivo, de pontes detonadas, de populações inteiras colocadas em condição de refugiados crônicos, de economias locais monitoradas e cerceadas em sua produtividade e distribuição de renda, entre tantos outros horrores. Ou seja, sob domínio de políticas públicas de viés esquerdistas ou neoliberais, o povo moçambicano, representado esteticamente no romance de Mia Couto que aqui estudamos, olha também desejoso para espacialidades utópicas, como que a procura de refrigério vital para a manutenção de sua vida e de sua rede coexistencial. 
Evasão da espacialidade infernal. Pulsão básica da vida diante outra pulsão básica que nos dirige para a morte, como promessa de equilibração psicossocial. Para preservar o frágil equilíbrio individual e coletivo é que os pais de Kindzu o exortam a continuar no território da casa familiar, mesmo que essa casa já se trate de um lugar inclementemente hibridizado pelas potências dos não lugares antropológicos.

Quando o rapaz decide tornar-se um Naparama, recusa, pois, os conselhos da tradição cautelar e protetiva, lançando-se no enfrentamentos dos espaços e dos tempos distópicos. No caminho, é perseguido por sonhos e age como um homem sonâmbulo, em consonância com a terra também sonâmbula. De seus vários sonhos, vão surgindo contextos de derrota ou de acomodação ao caos. O pai Taímo é reconstruído em tais sonhos, como aquele que amaldiçoa o filho que o desobedeceu e partiu, deixando a casa-raiz abandonada. Através desse sonho primeiro, o da suposta maldição paterna criada por Kindzu, grande parte de sua caminhada será envolta por desconfianças e falta de esperança nas relações humanas diante da necessidade de se criar meios para neutralizar a guerra civil e suas consequências.

Taímo, no entanto, não amaldiçoara o filho. Ao contrário, apesar de seus desvarios proféticos e conselhos para a sobrevivência da família e de sua coletividade, o pai acabava por instigar o filho a procurar seu lugar no mundo e a compreender como sua condição humana era produzida no entrelugar da tradição e dos novos valores, crenças e comportamentos da contemporaneidade imersa nos processos de descolonização político-cultural.

Essa ambiguidade formacional, que envolve nosso protagonista, pode ser acompanhada no último sonho do rapaz, já em densa peregrinação pela terra sonâmbula da guerra civil. Já bem perto de sua morte, observamos que Kindzu tem um longo sonho, no qual o feiticeiro de sua aldeia dirige uma longa fala ao seu povo. Essa fala inicialmente é envolta por um forte tom escatológico, no sentido de que o fim dos tempos está próximo e nada salvará aquela comunidade das selvagerias dos conflitos civis pós-coloniais. Vejamos tal registro onírico:

O feiticeiro subiu a um morro de muchém e contemplou a planície. Ajeitou o chapéu feito de penas e enroscou melhor a sarapilheira como se aquele calor lhe esfriasse os ossos. Então, levantando o seu cajado sentenciou: - Que morram as estradas, se apaguem os caminhos e desabem as pontes! ${ }^{8}$ Depois, começou o discurso,

\footnotetext{
8 "- Que morram as estradas, se apaguem os caminhos e desabem as pontes!" Sobre tal passagem, vale aqui lembrar que essa fala nos remete quase a um slogan de guerra de certa frente política moçambicana. Tal frente objetivava atacar as estruturas sociais de produção do primeiro governo do período pós-independência. A hipótese, aqui, é a de que Mia Couto tenta apresentar os dois projetos políticos para Moçambique pós-
}

desfiando palavras lentas, rasgando a voz de encontro ao vento: - Chorais pelos dias de hoje? Pois saibam que os dias que virão serão ainda piores. Foi por isso que fizeram esta guerra, para envenenar o ventre do tempo, para que o presente parisse monstros no lugar da esperança. Não mais procureis vossos familiares que saíram para outras terras em busca da paz. Mesmo que os reencontreis eles não vos reconhecerão. Vós vos convertêsseis em bichos, sem família, sem nação (COUTO, 2007, p. 118).

O feiticeiro, como depositário da sabedoria de grande parte da comunidade, alerta o seu povo para a falta de futuro que o aguarda. Seu ceticismo é baseado nas transformações dos seres humanos em animais, como aconteceram com Junhito, o irmão de Kindzu. Sua exortação ressalta o fracasso das tentativas de busca por familiares, por outras terras, pelo auxílio das tradições cautelares. Para ele, todos estão fatalmente convertidos em bichos, sem família e sem nação.

A distopia inclemente, dessa forma, avançaria pelos campos dos projetos feitos pela razão prática da reconstrução do homem moçambicano e de seus lugares antropológicos, construídos por seus desejos e interesses próprios.

O longo sonho final, entretanto, não termina no ponto da esperança perdida. Ao contrário, continua e tem seu registro deslocado. $\mathrm{O}$ feiticeiro, como que ressurgido das cinzas da descrença, aponta futuros possíveis, nos quais a população terá condições de sair da zoomorfização imposta de modo autoritário. No libertário deslocamento identitário e político, sua fala explicita e autoriza que:

No final, porém, restará uma manhã como esta, cheia de luz nova e se escutar uma voz longínqua como se fosse uma memória de antes de sermos gente. E surgirão os doces acordes de uma canção, o terno embalo da primeira mãe. Esse canto, sim, ser nosso, a lembrança de uma raiz profunda que não juram capazes de nos arrancar. Essa voz nos dar a força de um novo princípio e, ao escutá-la, os cadáveres sossegarão nas covas e os sobreviventes abraçarão a vida com o ingénuo entusiasmo dos namorados. Tudo isso se fará se formos capazes de nos despirmos deste tempo que nos fez animais. Aceitemos morrer como gente que já não somos. Deixai que morra o animal em que esta guerra nos converteu (COUTO, 2007, p. 118-119).

Os doces acordes de uma canção, os embalos maternos, os registros das várias linguagens haverão de

\footnotetext{
independência - o socialista inicial e o neoliberal que tentam manter diálogos ainda contemporaneamente. Tal representação tende a ser dialética no sentido de que a paz no país seria atingida quando tais forças políticas conseguissem produzir um governo inclusivo, expresso talvez por plataformas políticas multipartidárias, como relativamente vem acontecendo no país
} 
ter enraizamentos profundos e aplacarão as almas dos mortos. A condição para isso é a luta contra a animalização imposta pelos senhores da guerra, sejam eles de que frente política forem. Tal luta, nesse último sonho, é alegorizada pela transformação do irmão de Kindzu, de galo para ser humano novamente. Lembremo-nos de que Junhito fora disfarçado/transformado em galo pelo pai, com a finalidade de ter, mesmo que em vão, sua vida preservada. Com o irmão retornando à condição humana, várias pessoas do espaço onírico do protagonista também passam por tal mudança.

O fenômeno alegórico da volta à condição humana também atinge o velho Tuahir e o garoto Muidinga. De pessoas imersas na invisibilidades dos processos políticos e culturais e sua sociedade em crise, passam a agentes sociais capazes de alterar a ordem de seu socius. A narrativa ainda nos revela o segredo sobre a identidade familiar do garoto; no que não há muita importância para a economia narrativa. O mais importante aí, para nosso contexto analítico, parece ser o deslocamento estrutural da instituição que é a família, para a instituição maior, que é a coletividade heterogênea moçambicana, na qual o garoto é lançado, através da leitura que faz dos diários de Kindzu.

Nesse ponto final de nossa análise, voltamos às reflexões de Frantz Fanon sobre a condição do negro, em suas tentativas de desalienação diante contextos de crítica repressão estruturada tanto por condições etnorraciais e políticas:

O preto não é. Não mais do que o branco. Todos os dois têm de se afastar das vozes desumanas de seus ancestrais respectivos, a fim de que nasça uma autêntica comunicação. Antes de se engajar na voz positiva, há a ser realizada uma tentativa de desalienação em prol da liberdade. Um homem, no início de sua existência, é sempre congestionado, envolvido pela contingência. A infelicidade do homem é ter sido criança. É através de uma tentativa de retomada de si e de despojamento, é pela tensão permanente de sua liberdade que os homens podem criar as condições de existência ideais em um mundo humano. Superioridade? Inferioridade? Por que simplesmente não tentar sensibilizar o outro, sentir o outro, revelar-me outro? Não conquistei minha liberdade justamente para edificar o mundo do Ti? [...] Minha última prece: Ô meu corpo, faça sempre de mim um homem que questiona! (FANON, 2008, p. 191).

\section{Conclusão}

Terra solâmbula, romance incluso em várias listas dos melhores livros africanos do Século XX, traça-nos um panorama vigoroso e dialógico da sociedade moçambicana, em seu período pós-colonial. Nele, acompanhamos os protagonistas, Kindzu, Tuahir e Muindiga/Gaspar em dinâmica de composição subjetiva inclusiva e espelhada. Esta dinâmica supõe estratégias de sobrevivência psicossocial no período da guerra civil que dizimará grande parte da população local.

Os núcleos acionais são movimentados pelas constantes negociações multiculturais entre saberes tradicionais e inovações culturais dos tempos presentes. Entre lendas e folclores, os personagens se deslocarão para campos de resistência, nos quais a escrita/leitura assume seu papel educativo e dinamizador de ações críticas e ativas no contexto intergeracional, capacitando os agentes sociais a reconstruir/imaginar a nação que se deseja e que se pode ter.

Quanto à questão da formação de uma nova comunidade, que necessariamente atravessa os produtos culturais também vistos como produtos educativos, voltamos aqui, a Marc Augé. Este pensador, que também é reconhecido por suas vivências nos espaços africanos contemporâneos, reflete sobre a necessidade de uma mobilidade humana mais construtiva de espaços revolucionários em nossa época de regionalismos e globalizações em tensos diálogos. Para ele:

A educação deve inicialmente ensinar a todos a mudar o tempo para sair do eterno presente fixado pelas imagens em círculo, e fazer mudar o espaço, isto é, a mudar no espaço, a sempre ir ver mais de perto e a não se nutrir exclusivamente de imagens e mensagens. É preciso aprender a sair de si, a sair de seu entorno, a compreender que é a exigência do universal que relativiza as culturas e não o inverso. (AUGÉ, 2010, p. 109).

Ir mais perto dos variados fatos das realidades multidimensionais nas quais estamos imersos. Deslocarmo-nos de nossos entornos para compreendermos os movimentos multiculturais que nos conformam como agentes sociais capazes de co-autoriarmos nossos destinos. Essas são das camadas semânticas também responsáveis pela engenharia da diáspora psicossocial e das reconstruções/imaginações de Kindzu, que afetam diretamente os demais personagens da narrativa.

Se de início há o desejo da evasão de não lugares para lugares historicamente reconhecidos, do silêncio e da invisibilidade cautelar perante as desgraças da guerra, em seguida há a assumência dos lugares da resistência, demonstrada pela escrita dos diários. Pelos diários, volta-se à terra sonâmbula. Há, também, como que um despertar dessa terra que destruída e sonâmbula, nunca parara de se movimentar em transformações variadas que incluem historicamente as possibilidades de a humanidade também ressignificá-la, como ocorre nas ações e reações finais de Kindzu: 
Me apetece deitar, me anichar na terra morna. Deixo cair ali a mala onde trago os cadernos. Uma voz interior me pede para que não pare. É a voz de meu pai que me dá força. Venço o torpor e prossigo ao longo da estrada. Mais adiante segue um miúdo com passo lento. Nas suas mãos estão papéis que me parecem familiares. Me aproximo e, com sobressalto, confirmo: são os meus cadernos. Então, com o peito sufocado, chamo: Gaspar! E o menino estremece como se nascesse por uma segunda vez. De sua mão tombam os cadernos. Movidas por um vento que nascia não do ar mas do próprio chão, as folhas se espalham pela estrada. Então, as letras, uma por uma, se vão convertendo em grãos de areia e, aos poucos, todos meus escritos se vão transformando em páginas de terra. (COUTO, 2007, p. 119-120).

\section{Referências}

ANDERSON, Benedict. Comunidades imaginadas: reflexões sobre a origem e a difusão do nacionalismo. Tradução de Denise Bottman. São Paulo: Companhia das Letras, 2008.

ANDERSON, Benedict. Nação e consciência nacional. Tradução de Lólio Lourenço de Oliveira. São Paulo: Ática, 1989.

AUGÉ, Marc. Não lugares: introdução a uma antropologia da supermodernidade. Tradução de Maria Lúcia Pereira. Campinas: Papirus, 2012.

AUGÉ, Marc. Por uma antropologia da mobilidade. Tradução de Bruno César Cavalcanti e Rachel Rocha de Almeida. Maceió: EDLTFAL/UNESP, 2010.

COELHO, João Paulo Borges. A "literatura quantitativa" e a interpretação do conflito armado em Moçambique. In <www. ces.uc.pt/estilhacos_do_imperio/comprometidos $>$. Acesso em: 12 jun. 2016.
COUTO, Mia. Official Website. <http://www.miacouto.org>. Acesso em: 07 jun. 2016.

COUTO, Mia. Estórias abensonhadas. Lisboa: Editorial Caminho, 2009.

COUTO, Mia. Terra sonâmbula. São Paulo: Cia. das Letras, 2007.

DINERMAN, Alice. Revolution, Counter-Revolution and Revisionism in Postcolonial Africa: The Case of Mozambique, 1975-1994. Londres/Nova York: Routledge, 2006.

FANON, Frantz. Pele negra, máscaras brancas. Tradução de Renato da Silveira. Salvador: EDUFBA, 2008.

FANON, Frantz. Os condenados da terra. 2. ed. Prefácio de Jean-Paul Sartre. Tradução de José Laurenio de Melo. Rio de Janeiro: Civilização Brasileira, 1979.

GOVERNO de Moçambique. Portal do Governo de Moçambique. <http://www.portaldogoverno.gov.mz>. Acesso em: 02 jun. 2016.

MANHEIM, Karl. O problema sociológico das gerações. In: FORACCHI, Marialice M. (Org.). Sociologia e sociedade: leituras de introdução à Sociologia. São Paulo: Ática. 1982.

SPIVAK, Gayatri Chakravorty. Pode o subalterno falar? Tradução de Sandra Regina Goulart Almeida, Marcos Pereira Feitosa e André Pereira Feitosa. Belo Horizonte: Editora UFMG, 2010.

SPIVAK, Gayatri Chakravorty et al. Estudios postcoloniales: ensayos fundamentales. Traducción de Marta Malo Madri: Queimadas Graficas, 2008.

VENÂNCIO, José Carlos. Literatura e poder na África Lusófona. Lisboa: Ministério da Educação. Instituto de Cultura e Língua Portuguesa, 1992.

Recebido: 15 de abril de 2016. Aprovado: 02 de julho de 2016. Contato: jorgeufg@bol.com.br 